\title{
OBOWIAZZEK PRACY NA CELE SPOŁECZNE JAKO ELEMENT KARY KRYMINALNEJ
}

\section{OBOWIAZZEK PRACY W RAMACH KARY W POLSKICH KODEKSACH KARNYCH}

Praca jako obowiązek wykonywany w ramach kary kryminalnej znana była już Kodeksowi karnemu z 1932 r., co więcej: stanowiła ona na gruncie tego kodeksu ,zasadę nie dopuszczająca przełamania” w przypadku skazania na karę więzienia (art. 39 k.k. 32) lub aresztu (art. $40 § 2$ k.k. 32). W wypadku obu tych sankcji Kodeks karny przewidywał bowiem obowiązek pracy skazanego; przy czym o ile w przypadku kary aresztu skazany zobowiązany był zając się pracą, ale rodzaj zajęcia mógł on wybrać sam (dopiero w razie stwierdzenia, że praca wybrana przez niego narusza wewnętrzny porządek zakładu lub aresztant żadną pracą zająć się nie chce, zarząd zakładu karnego sam wyznaczał mu pracę), o tyle w przypadku kary więzienia rodzaj pracy był mu narzucany przez zarząd zakładu karnego. Zróżnicowanie takie uzasadniano przez wskazanie, że ,,praca w więzieniu musi być jednak przykrzejsza, niż w areszcie, czynnik zawisłości musi być silniej podkreślony, więzień nie może wybrać rodzaju pracy. Zarząd zakładu rozporządzając więźniem i dobierając dla niego rodzaj kary przyjemniejszy lub mniej przyjemny, ma w rękach skuteczny środek pedagogiczny" ${ }^{1}$. O dolegliwości związanej z wykonywaniem kary pozbawienia wolności - i w jej ramach świadczenia pracy - miał zatem decydować rodzaj przydzielonej skazanemu pracy oraz możliwość (lub brak możliwości) jej wyboru.

W Kodeksie karnym z 1969 r. obowiązek pracy w postaci nieodpłatnego dozorowanego świadczenia na cele publiczne został włączony do nowego rodzaju kary o charakterze wolnościowym - ograniczenia wolności, w wymiarze od 3 miesięcy do 2 lat. Geneza tej kary była już wielokrotnie przedmiotem analiz. Wywodzono ją od kary pracy poprawczej (przejętej z ustawodawstwa radzieckiego), aresztu domowego bądź ze złagodzonych reżimów wykonywania kary pozbawienia wolności ${ }^{2}$. Kara ta miała stanowić alternatywę dla krótkoterminowych kar pozbawienia wolności, izolując skazanego od środowiska przestępczego, z jakim stykałby się w razie wykonania takiej kary ${ }^{3}$. Natomiast jej

\footnotetext{
1 J. Makarewicz, Kodeks karny z komentarzem, Lwów 1935, s. 172.

${ }^{2}$ Szerzej: J. Skupiński, Kara ograniczenia wolności w prawie karnym powszechnym - jej istota, geneza i prawnomiedzynarodowe uwarunkowania, „Studia Prawnicze” 1988, z. 4, s. 62-68.

${ }^{3}$ Szerzej: R. Giętkowski, Kara ograniczenia wolności w polskim prawie karnym, Warszawa 2007, s. 16 .
} 
zakładana dolegliwość miała się wyrażać w zatrudnieniu skazanego w wymiarze 20-50 godzin miesięcznie poza normalnymi godzinami pracy lub w dni wolne od pracy, w nieodpłatnym i dozorowanym trybie jej odbywania, jak też w pozostałych ograniczeniach składających się na tę karę, jak: zakaz zmiany miejsca stałego pobytu bez zgody sądu, pozbawienie prawa sprawowania funkcji w organizacjach społecznych czy obowiązek udzielania wyjaśnień dotyczących przebiegu odbywania kary ${ }^{4}$. Podkreślano bowiem, że sama praca, która zgodnie z art. 19 pkt 1 Konstytucji PRL z 1952 r. - jest „,prawem, obowiązkiem i sprawą honoru każdego obywatela", nie może być traktowana jak dolegliwość; taką dolegliwością mogą być natomiast warunki jej odbywania w postaci ograniczenia swobody wyboru rodzaju i miejsca pracy, braku możliwości awansu i udziału w organizacjach społecznych, jak też braku lub zmniejszenia wynagrodzenia ${ }^{5}$.

Względem sprawcy, który nie pozostawał w stosunku zatrudnienia, możliwe było orzeczenie zamiast pracy świadczonej nieodpłatnie pracy ze zmniejszonym wynagrodzeniem (od 10 do $25 \%$ ) w uspołecznionym zakładzie pracy. Jeżeli natomiast sprawca już był zatrudniony w uspołecznionym zakładzie pracy, to możliwe było potrącenie - w miejsce wykonywania pracy wskazanej przez sąd od 10 do 25\% wynagrodzenia na rzecz Skarbu Państwa albo na cel społeczny wskazany przez sąd. Taka forma wykonywania kary ograniczenia wolności połączona była $\mathrm{z}$ dolegliwościa $\mathrm{w}$ postaci zakazu rozwiązania w czasie jej trwania stosunku pracy bez zgody sądu oraz niemożności przyznania skazanemu wyższego wynagrodzenia ani przeniesienia go na wyższe stanowisko.

Wymierzając karę ograniczenia wolności, sąd mógł zobowiązać skazanego do naprawienia w całości albo części szkody wyrządzonej przestępstwem lub do przeproszenia pokrzywdzonego. Obowiązki te o charakterze kompensacyjnym, trudno uznać jednak za dolegliwość w rozumieniu karnoprawnym; nie obciążaja one bowiem sprawcy czymś, do czego nie byłby prawnie lub moralnie zobowiązany na podstawach spoza prawa karnego.

W projekcie Kodeksu karnego w 1997 r. wskazano, że zakłada się orzekanie kary ograniczenia wolności w stosunku do sprawców, którzy nie moga uiścić grzywny, oraz wówczas, gdy ukaranie grzywną byłoby niecelowe (np. za przestępstwo niealimentacji), a kara pozbawienia wolności jawi się jako zbyt surowa ${ }^{6}$. Obowiązek wykonywania pracy wskazanej przez sąd (obecnie: nieodpłatnej kontrolowanej pracy na cele społeczne) wymierzany alternatywnie $\mathrm{z}$ potrąceniem 10-25\% wynagrodzenia za pracę $\mathrm{w}$ stosunku miesięcznym (powiązanym z zakazem rozwiązania stosunku pracy w okresie odbywania kary bez zgody sądu), został połączony z dwoma obligatoryjnymi obowiązkami: zakazem zmiany miejsca stałego pobytu bez zgody sąu i obowiązkiem udzielania wyjaśnień dotyczących przebiegu odbywania kary. Karę ograniczenia wolności skrócono do wymiaru od miesiąca do 12 miesięcy pozbawienia wolności ${ }^{7}$, a świadczenie pracy - do wymiaru od 20 do 40 godzin w stosunku

\footnotetext{
${ }^{4}$ Por. I. Andrejew, W. Świda, W. Wolter, Kodeks karny z komentarzem, Warszawa 1973, s. 181-185.

${ }^{5}$ I. Andrejew, Polskie prawo karne w zarysie, Warszawa 1976, s. 256.

${ }^{6}$ Por. uzasadnienie projektu Kodeksu karnego. Wkładka do zeszytu 3/1994 „Państwa i Prawa”,

${ }^{7}$ Por. przytaczane w literaturze wyniki studiów nad praca na cele społeczne w innych krajach
} s. 25. 
miesięcznym. Przewidziano również dodatkowe obowiązki, które można było na sprawcę nałożyć fakultatywnie (obecnie wszystkie obowiązki z art. 72 k.k.), fakultatywny dozór (obecnie regulowany przez Kodeks karny wykonawczy [k.k.w] oraz (obecnie uchylony) obowiązek wysłuchania przez sąd skazanego co do miejsca i sposobu wykonywania pracy, który miał mieścić w sobie założenie, że skazany przyjął na siebie obowiązek pracy i związane z nim ograniczenie wolności ${ }^{8}$. Jako formę zachęty do sumiennego wykonywania wskazanej pracy, przestrzegania porządku prawnego oraz spełniania nałożonych na skazanego obowiązków i orzeczonych środków karnych przewidziano możliwość zwolnienia skazanego nawet z połowy kary pozostałej do odbycia, uznając ją za wykonaną (art. 83 k.k.).

\section{ROZDZIELENIE KARY OGRANICZENIA WOLNOŚCI I ŚWIADCZENIA PRACY SPOŁECZNIE UŻYTECZNEJ NA PRZYKŁADZIE KODEKSU KARNEGO FEDERACJI ROSYJSKIEJ}

Źródła koncepcji świadczenia pracy jako obowiązku w ramach kary wolnościowej poszukiwano $\mathrm{w}$ stosowanej $\mathrm{w}$ ustawodawstwie radzieckim karze pracy poprawczej; zaznaczając jednocześnie, że oczekiwania co do wychowawczego charakteru tej kary nie sprawdziły się . Takie wskazanie pociaga za soba pytanie, czy w obecnie obowiazujacym systemie kar w Kodeksie karnym Federacji Rosyjskiej z 1996 r. (dalej jako: k.k. FR) istnieje odpowiednik kary powiązanej z obowiązkiem świadczenia pracy.

Katalog kar został ujęty w art. 44 k.k. FR i zaliczono do niego, obok kary ograniczenia wolności (ограничение свободы) między innymi prace obowiązkowe (обязательные работы) і prace poprawcze (исправительные работы). Ograniczenie wolności, którego zakres ujęto w art. 53 ust. 1 k.k. FR, oznacza nałożenie przez sąd na skazanego ograniczeń w postaci: zakazu opuszczenia miejsca zamieszkania $\mathrm{w}$ określonych godzinach $\mathrm{w}$ ciągu doby, zakazu przebywania $\mathrm{w}$ określonych miejscach znajdujących się $\mathrm{w}$ granicach danej jednostki administracyjnej, zakazu wyjeżdżania poza granice danej jednostki administracyjnej, zakaz przebywania $\mathrm{w}$ miejscu imprez masowych i innych oraz uczestniczenia we wskazanych imprezach, zakazu zmiany miejsca stałego lub czasowego pobytu, miejsca pracy lub nauki bez zgody właściwego organu państwowego sprawującego nadzór nad wykonaniem kary ograniczenia wolności. Ograniczenie wolności jest orzekane na okres od 2 miesięcy do 4 lat jako samodzielna kara za przestępstwa o średniej wadze i na okres od 6 miesięcy do 2 lat jako kara dodatkowa przy wymierzeniu kary pozbawienia wolności w przypadkach określonych w części szczególnej Kodeksu.

Prace obowiązkowe, uregulowane w art. 49 k.k. FR, to w prawie rosyjskim nowy, samodzielny rodzaj kary polegający na wykonywaniu przez skazanego

europejskich, które wykazały, że orzekana na okres dłuższy niż rok staje się nieefektywna, gdyż po upływie tego okresu jest przez skazanych przerywana. M. Szewczyk, Kara pracy na cele spoteczne na tle rozważań o przestepstwie i karze. Studium prawnoporównawcze, Kraków 1996, s. 213.

${ }^{8}$ Por. uzasadnienie, s. 25.

${ }^{9}$ Szerzej: R. Giętkowski, op. cit., s. 15-19. 
bezpłatnej pracy społecznie użytecznej w czasie wolnym od innej pracy lub nauki. Rodzaj pracy i jednostki, w której ma ona być świadczona, określane sa przez organy lokalnego samorządu $\mathrm{w}$ porozumieniu $\mathrm{z}$ inspekcjami karno-wykonawczymi. Prace obowiązkowe wymierzane są w rozmiarach od 60 do 240 godzin i wykonywane w wymiarze nie większym niż 4 godziny dziennie; ale też bez uzasadnionej przyczyny - nie mniejszym niż 12 godzin tygodniowo. W razie zmiany miejsca zamieszkania konieczne jest zawiadomienie o tym właściwej inspekcji karno-wykonawczej ${ }^{10}$.

Samodzielna kara prac poprawczych była znana prawu rosyjskiemu już wcześniej i przed wejściem w życie Kodeksu karnego Federacji Rosyjskiej z $1996 \mathrm{r}$. miała formę prac poprawczych w miejscu pracy skazanego albo $\mathrm{w}$ miejscu wskazanym przez organy wykonawcze; następnie wymierzano ja tylko skazanemu mającemu miejsce pracy ${ }^{11}$. Obecnie, zgodnie z art. 50 k.k. FR, karę tę wymierza się skazanemu, który nie ma innego miejsca pracy, i wykonuje się w miejscu określonym przez organy lokalnego samorządu w porozumieniu z właściwym dla tej kary organem wykonawczym, w obszarze miejsca zamieszkania skazanego. Prace poprawcze wymierza się w rozmiarze od 2 miesięcy do 2 lat; z pracy skazanego dokonuje się $\mathrm{w}$ tym czasie potraceń na rzecz państwa w rozmiarze określonym w wyroku sądowym (od 5 do 20\%). Dodatkowym ograniczeniem jest niemożność rozwiązania stosunku pracy bez pisemnej zgody inspekcji karno-wykonawczej, a także uzależnienie możliwości skorzystania z płatnego urlopu od zgody pracodawcy i wskazanej inspekcji ${ }^{12}$.

Powyższy stan prawny istniejący w Federacji Rosyjskiej rodzi pytanie, dlaczego w Polsce obowiązek pracy na cele społeczne został włączony do kary ograniczenia wolności, względnie może stanowić jeden ze obowiązków probacyjnych na gruncie art. $72 \S 1$ k.k., zamiast tworzyć samoistny rodzaj sankcji. Przyczyny takiego stanu rzeczy wydają się tkwić głównie w kontekście historycznym. Ponieważ obligatoryjne obowiązki z art. $34 \S 2$ k.k., towarzyszące obowiązkowi pracy na cele społeczne, w zasadzie nie wypływają na specyfikę tej kary, sprowadzenie obowiązków związanych z karą ograniczenia wolności do samego świadczenia pracy na cele społeczne wydaje się możliwe. Zasadne byłoby w takim wypadku najwyżej zwiększenie jej ustawowo przewidzianego wymiaru godzinowego i rezygnacja $\mathrm{z}$ alternatywnych potrącen $\mathrm{z}$ wynagrodzenia, które przyjęłoby w takim wypadku formę grzywny rozłożonej na kilka miesięcznych rat; $\mathrm{z}$ takim postulatem można spotkać się zresztą od pewnego czasu w literaturze ${ }^{13}$. Wprawdzie wskazuje się, że badania empiryczne prowadzone w Polsce w latach siedemdziesiątych wykazały mniejszą powrotność do przestępstwa u skazanych, względem których stosowano wariant potrącenia części wynagrodzenia niż u zobowiązanych do świadczenia pracy. Jednak odpowiedzią na ten wynik może być argument, że skazani z pierwszej grupy (ci, u których dokonywano potrąceń) prawdopodobnie kwalifikowali się po

${ }^{10}$ G. A. Stjeniczkin, A. W. Brilliantow, w: A. W. Brilliantow (red.), Ugolovnoe pravo Rossii, Moskwa 2010 , s. 256.

11 Ibidem, s. 259.

12 A. W. Brilliantow, S. A. Razumow, w: A. W. Brilliantow (red.), Kommentarij k Ugolovnomu kodeksu Rossijskoj Federacii, Moskwa 2010, s. 158.

${ }^{13}$ Por. M. Szewczyk, op. cit., s. 201-202. 
prostu do wymierzenia im kary grzywny - zatem na tej podstawie nie można mówić o nieefektywności lub mniejszej efektywności pracy świadczonej na cele społeczne jako formy sankcji karnej ${ }^{14}$.

\section{III. ŚWIADCZENIE PRACY NA CELE SPOŁECZNE A DOLEGLIWOŚĆ KARY OGRANICZENIA WOLNOŚCI}

Zgodnie z art. $53 \S 1$ k.k.w., wykonanie kary ograniczenia wolności ma na celu wzbudzenie w skazanym woli kształtowania jego społecznie pożądanych postaw, w szczególności poczucia odpowiedzialności oraz potrzeby przestrzegania porządku prawnego. Regulacja ta wskazuje, że na etapie wykonywania kary związanej ze świadczeniem pracy na cele społeczne nacisk kładzie się na jej resocjalizujący charakter. Ponieważ jednak ograniczenie wolności jest karą, musi ona wiązać się z dyskomfortem i dolegliwością, a zatem z zastosowaniem przymusu i ograniczeniem swobód oraz wolności skazanego ${ }^{15}$. Ustalenie, co stanowi tę dolegliwość w przypadku kary ograniczenia wolności, jest istotne dla rozłożenia obowiązków sądu w procesie wymierzania i wykonywania tej kary. Dolegliwość związana z kara powinna być bowiem zidentyfikowana i zastosowana na etapie wymiaru kary (a nie dopiero podczas jej wykonywania), gdyż to na tym etapie wiąże się ją ze stopniem winy i pozostałymi dyrektywami jej wymiaru.

Dolegliwością cechująca karę jest $\mathrm{z}$ jednej strony fakt jej wymierzenia i wpisu informacji o skazaniu do Krajowego Rejestru Karnego, a z drugiej strony - poddanie mniej lub bardziej szczegółowej kontroli określonej sfery życia skazanego i ograniczenie jego swobód w tym zakresie. Tak jest jednak przy wszystkich rodzajach kar. Obowiązkiem uznawanym za decydujący o istocie kary ograniczenia wolności, a zatem decydujący o jej stopniu dolegliwości, jest natomiast wykonywanie pracy na cele społeczne ${ }^{16}$.

Postrzeganie obowiązku świadczenia pracy na cele społeczne jako dolegliwości budzi jednak zastrzeżenia od dłuższego czasu. Jak wskazano wyżej, na gruncie Kodeksu karnego z 1969 r. w odniesieniu do kary ograniczenia wolności podkreślano, że wartość, jaką stanowi praca, nie pozwala traktować jej jako dolegliwość ${ }^{17}$; argument ten - pomimo zmienionych warunków politycznych zachował aktualność, zwłaszcza w okresach nasilonego bezrobocia. Stąd dolegliwości doszukiwano się innych obowiązkach związanych z karą ograniczenia wolności: w zakazie zmiany miejsca stałego pobytu bez zgody sądu czy obowiązku udzielania wyjaśnień dotyczących przebiegu odbywania kary. Porównanie tych obowiązków z obowiązkiem wykonywania nieodpłatnej, kontrolo-

\footnotetext{
14 Por. M. Szewczyk, op. cit., s. 201.

${ }^{15}$ Ibidem, s. 28-36. Choć autorka wskazuje, że ograniczenie sankcji do obowiązku naprawienia szkody jest dopuszczalne w sytuacjach wyjątkowych, uzasadnionych niskim stopniem winy i społecznej szkodliwości czynu.

${ }^{16}$ W. Wróbel, Opinia prawna z 29.01.2009 r. o rzadowym projekcie ustawy o zmianie o zmianie ustawy - Kodeks karny, ustawy - Kodeks postępowania karnego, ustawy - Kodeks karny wykonawczy, ustawy - Kodeks karny skarbowy oraz niektórych innych ustaw (druk sejmowy nr 1394), s. 5.

17 I. Andrejew, op. cit., s. 256.
} 
wanej pracy na cele społeczne, nie pozostawia jednak wątpliwości co do tego, który z obligatoryjnych elementów kary ograniczenia wolności stanowi jej trzon. Dolegliwości szukano także $\mathrm{w}$ warunkach wykonywania pracy związanych z czasowym ograniczeniem wybranych swobód i wolności na rzecz świadczeń społecznych, w postaci ograniczenia swobody wyboru rodzaju i miejsca pracy, braku lub zmniejszeniu wynagrodzenia, wykonywania pracy pod kontrola czy też w fakcie odebrania sprawcy części jego wolnego czasu, który mógł być przeznaczony na wypoczynek lub - przykładowo - na świadczenie dodatkowej odpłatnej pracy według wyboru sprawcy ${ }^{18}$. Należy jednak wskazać, że samoistna dolegliwością nie jest ani nieodpłatny charakter pracy (wolontariat nie jest bowiem postrzegany negatywnie), ani wykonywanie jej pod kontrola (istota stosunku pracy jest wykonywanie jej pod kierownictwem). Ani zatem nazwa sankcji, ani dookreślenie warunków jej wykonywania (które wynikaja raczej z okoliczności jej świadczenia niż celowego miarkowania dolegliwości) nie moga przesłonić faktu, że istotą kary ograniczenia wolności, w której zawiera się jej dolegliwość, jest obowiązek pracy na cele społeczne. Aby przy tym uniknąć nieporozumień, należy podkreślić, że praca na cele społeczne sama w sobie dolegliwością nie jest; dolegliwością staje się dopiero wówczas, gdy jest świadczona jako forma (lub element) kary.

W literaturze wskazywano, że sąd wymierzając karę ograniczenia wolności, powinien jednocześnie określić rodzaj pracy, która ma być wykonywana w jej ramach, gdyż przemawia za tym wpływ rodzaju nakazanej pracy na dolegliwość kary i czuwanie nad tym, by dolegliwość orzeczonej kary była współmierna do stopnia winy sprawcy i społecznej szkodliwości jego czynu ${ }^{19}$. Sugeruje to jednak, że rodzaj pracy na cele społeczne może być bardziej lub mniej dolegliwy dla sprawcy, co wydaje się koncepcyjnie (choć niekoniecznie faktycznie) tezą wątpliwą. Oznaczałoby to bowiem, że sąd powinien kierować się wskaźnikiem, zgodnie z którym - przykładowo - im mniejsze sprawca ma predyspozycje (w rozumieniu umiejętności, ale także predyspozycji psychicznych) lub wolę (ze względu na odbieranie określonego charakteru pracy jako bardziej przykrego) do świadczenia danej pracy, a zatem im trudniej będzie mu ją wykonywać, tym bardziej dolegliwa będzie dla niego kara. Wymagałoby to jednak szczegółowej analizy psychiki i umiejętności sprawcy, na co w toku postępowania karnego nie ma zwykle ani warunków, ani czasu; stałoby również w sprzeczności z założeniem, że sam fakt pracy wykonywanej w ramach kary ograniczenia wolności ma z zasady oddziaływać na sprawcę pozytywnie. Przy wyborze konkretnego rodzaju pracy w ramach wykonywania kary ograniczenia wolności nie chodzi o odczucia, jakie sprawca żywi względem pracy określonego rodzaju, lecz o potrzeby danej społeczności. Wymiar kary i związana z nim dolegliwość zawierają się w rozmiarach (okresie, liczbie godzin czy procencie potrącanego wynagrodzenia) wymierzonej kary, a nie w jej rodzaju. Stąd wyłączenie z obowiązków sądu określania konkretnego sposobu, czasu i miejsca wykonywania nieodpłatnej i kontrolowanej pracy należy uznać za uzasadnione również z punktu widzenia dyrektyw wymiaru kary.

18 Por. J. Skupiński, op. cit., s. 61.

19 R. Giętkowski, op. cit., s. 23. 


\section{IV. ŚWIADCZENIE PRACY NA CELE SPOŁECZNE A PRACA PRZYMUSOWA LUB OBOWIĄZKOWA}

Okoliczność, że dolegliwość stanowiąca istotę kary ograniczenia wolności może przyjąc formę świadczenia pracy, prowadzi do jednego z najczęściej rozważanych problemów w kontekście kary ograniczenia wolności - problemu zgodności ujęcia pracy jako formy przymusu wiążącego się $\mathrm{z}$ sankcją karną z umowami międzynarodowymi zabraniającymi pracy przymusowej lub obowiązkowej, których stroną jest Rzeczpospolita Polska. W tym kontekście wskazuje się na art. 2 Konwencji nr 29 Międzynarodowej Organizacji Pracy dotyczacej pracy przymusowej lub obowiązkowej (dalej: Konwencja nr 29 MOP) $)^{20}$, art. 4 ust. 2 Europejskiej konwencji o ochronie praw człowieka i podstawowych wolności (dalej: EKPC) ${ }^{21}$ oraz art. 8 pkt 3 Międzynarodowego paktu praw obywatelskich i politycznych (dalej: MPPOiP) ${ }^{22}$. O ile art. 2 lit. c Konwencji nr 29 MOP wyłącza z zakresu pojęcia ,pracy przymusowej lub obowiązkowej" w rozumieniu tej konwencji wszelką pracę lub usługi wymagane od jakiejś osoby w wyniku skazania jej przez władzę sądową pod warunkiem, że ta praca lub te usługi będa wykonywane pod nadzorem i kontrolą władz publicznych i że ta osoba nie będzie najęta lub oddana do rozporządzenia jednostkom, prywatnym spółkom lub stowarzyszeniom, o tyle już pojęcie ,,pracy przymusowej lub obowiązkowej" zawarte w pozostałych dwóch konwencjach tak szerokiego wyłączenia nie dopuszcza. Artykuł 4 ust. 2 EKPC stanowi, że nikt nie może być zmuszony do świadczenia pracy przymusowej lub obowiązkowej; ale - zgodnie z art. 4 ust. 3 lit. a EKPC - w rozumieniu tego artykułu pojęcie „,pracy przymusowej lub obowiazkowej” nie obejmuje: żadnej pracy, jakiej wymaga się zwykle w ramach wykonywania kary pozbawienia wolności orzeczonej zgodnie z postanowieniami art. 5 niniejszej Konwencji lub w okresie warunkowego zwolnienia. Również w art. 8 ust. 3 MPPOiP przewidziano zakaz pracy przymusowej lub obowiązkowej, z którego wyjęto między innymi zakaz wykonywania ciężkiej pracy zgodnie $\mathrm{z}$ wyrokiem właściwego sądu w krajach, w których pozbawienie wolności połączone z ciężkimi robotami może być orzeczone jako kara za zbrodnie oraz zakaz innego rodzaju pracy lub świadczeń zwykle wymaganych od osób pozbawionych wolności na skutek prawomocnego orzeczenia sądu lub od osób w okresie warunkowego zwolnienia od takiego pozbawienia wolności.

Argumentacja a maiori ad minus, zgodnie z która skoro przymus pracy jest dopuszczalny w warunkach pozbawienia wolności jako kary, to tym bardziej należy go dopuścić w ramach kary wolnościowej ${ }^{23}$, może być skutecznie podważona. W literaturze wskazuje się bowiem, że tylko Konwencja nr 29 MOP z 1930 r. dopuszcza nakładanie na jednostkę obowiązku świadczenia pracy przez władzę sądowa w drodze kary bez ograniczenia jej charakteru do kary pozbawienia wolności. Natomiast w późniejszych konwencjach dotyczących

\footnotetext{
${ }^{20}$ Dz. U. 1959, Nr 20, poz. 122.

21 Dz. U. 1993, Nr 61, poz. 284.

22 Dz. U. 1977, Nr 38, poz. 167.

${ }^{23}$ G. Pfohl, cyt. za: R. Giętkowski, op. cit., s. 22; M. Szewczyk, op. cit., s. 39.
} 
pracy przymusowej (EKPC z 1950 r. i MPPOiP z 1966 r.) zawężono zakres dopuszczalnych wyjątków stosowania pracy niedobrowolnej do wykonywania jej w ramach lub w związku z karą pozbawienia wolności, co należy uznać za zabieg celowy, związany ze zmianą pojmowania praw człowieka i akceptowalnych ingerencji w tym zakresie od ograniczenia najbardziej drastycznych form wyzysku do wprowadzania gwarancji tych praw w coraz szerszym zakresie ${ }^{24}$.

Również sugestia, by usunąć przymusowy charakter pracy wykonywanej w ramach kary ograniczenia wolności poprzez uzależnienie jej orzekania i wykonywania od zgody skazanego, znajduje odpowiedź we wskazaniu, że uzgadnianie ze skazanym (bądź jeszcze z oskarżonym) rodzaju kary stoi w sprzeczności z jej istota jako formą sankcji nakładanej na skazanego, a nie negocjowanej $\mathrm{z}$ nim formy zadośćuczynienia za wyrządzone zło, co byłoby typowe raczej dla prawa cywilnego ${ }^{25}$. Negocjowanie warunków odbywania kary z oskarżonym, który nie przyznaje się do winy, byłoby nadto sprzeczne z zasada domniemania niewinności (art. $5 \$ 1$ k.p.k.) oraz gwarancją bezstronności sądu (art. 45 ust. 1 Konstytucji RP oraz art. 4 k.p.k.), który do czasu ogłoszenia wyroku nie powinien wypowiadać się na temat przewidywanej treści, ani nawet kierunku swojego rozstrzygnięcia ${ }^{26}$. Wskazuje się także, że zgoda na pracę społecznie użyteczną w warunkach zagrożenia zastosowaniem kary pozbawienia wolności jest udzielana w warunkach przymusu, a zatem pozbawiona jest elementu dobrowolności, który usuwałby zarzut świadczenia pracy niedobrowolnej ${ }^{27}$. Ponadto jeżeli praca społecznie użyteczna ma być elementem sankcji karnej, konieczne jest by wiązała się ona z pewnym przymusem, który stanowi nieodłączny element kary kryminalnej. Nie wydaje się zatem możliwe pogodzenie dobrowolności świadczenia pracy w ramach kary kryminalnej z przymusem jako dolegliwością stanowiąca istotę tej kary, chyba że prawo karne z formy reakcji państwa na naruszenie ustanowionych reguł postępowania stanie się polem do prowadzenia negocjacji między równorzędnymi partnerami.

Wprawdzie możliwe jest jeszcze wymierzanie sprawcy warunkowej kary pozbawienia wolności i modyfikowanie tej kary poprzez przekształcanie jej na etapie wykonawczym w karę ograniczenia wolności w sytuacji, w której sprawca wyrazi zgodę na świadczenie pracy w warunkach wolnościowych ${ }^{28}$. Jednakże

${ }^{24}$ J. Skupiński, op. cit., s. 71-73.

${ }^{25}$ Por. H. J. Hirsch, Schadenwiedergutmachung in materiellen Strafrecht, „Zeitschrift für die gesamte Strafrechtswissenschaft" 102, 1990, s. 536-537.

${ }^{26}$ Por. wyrok SN - Izba Karna z 18 marca 2009 r. (IV KK 380/08, „Krakowskie Zeszyty Sądowe” 2009, nr 6, poz. 32), w którym wskazano, że: „Zasada domniemania niewinności wiąże się ściśle z wyrażoną w art. 4 KPK zasadą obiektywizmu. Oznacza ona nakaz bezstronnego traktowania stron, w tym oskarżonego, oraz zakaz kierunkowego nastawienia do sprawy, więc sąd nie może przyjmować określonego obrazu sprawy przed zakończeniem postępowania i dawać stronom do zrozumienia, że ma już określoną wersję zdarzenia w przedmiocie odpowiedzialności. Uzewnętrznienie swojego stanowiska, między innymi poprzez wydanie orzeczenia w innej sprawie pozostającej w związku ze sprawą aktualnie rozpoznawaną lub przez sposób uzasadnienia takiego rozstrzygnięcia, uznawane jest za powód do powstania uzasadnionej wątpliwości co do bezstronności sędziego w danej sprawie”.

${ }^{27}$ Por. M. Szewczyk, op. cit., s. 91-92; J. Skupiński, op. cit., s. 76.

${ }^{28}$ Zbliżona propozycja, zakładająca jednak wymierzenie pierwotnie kary ograniczenia wolności, a następnie uzależnienie jej wykonania (lub zamianę na grzywnę albo karę pozbawienia wolności) od zgody sprawcy na świadczenie pracy społecznie użytecznej, została przedstawiona przez B. Kunicką- 
czynienie z kary ograniczenia wolności sposobu wykonywania kary pozbawienia wolności stanowiłoby zabieg co najmniej sztuczny, zwłaszcza że obecnie w takiej sytuacji można po prostu skorzystać z wykonywania kary pozbawienia wolności w systemie dozoru elektronicznego (stosowanego na wniosek skazanego) połaczonego $\mathrm{z}$ obowiązkiem świadczenia pracy, możliwym do ustanowienia na gruncie art. 8 ust. 2 ustawy z 7 września 2007 r. o wykonywaniu kary pozbawienia wolności poza zakładem karnym $\mathrm{w}$ systemie dozoru elektronicznego ${ }^{29}$ w zw. z art. $72 \S 1$ pkt 4 k.k.

Skoro ograniczenie wolności jest karą, a jej trzon stanowi praca na cele społeczne, to praca ta stanowi podstawę odczuwania dolegliwości zawartej w tej sankcji, a zatem czynnik powodujący dyskomfort u sprawcy. Okoliczność ta powinna być brana pod uwage przy wymiarze kary oraz stosowaniu dodatkowych obowiązków na gruncie art. $72 \S 1$ k.k., aby ostatecznie łącznie ukształtowana kara nie przekroczyła stopnia winy sprawcy, jak też pozostawała w zgodzie z pozostałymi dyrektywami wymiaru kary z art. $53 \S 1$ k.k.

Nie da się zatem, jak się wydaje, uniknąć stwierdzenia, że praca na cele społeczne jako element (lub forma) kary kryminalnej łączy się z przymusem, a zatem - jako nałożona orzeczeniem sądu - wykonywana jest niedobrowolnie. $\mathrm{W}$ tej sytuacji pozostaje do rozważania kwestia umieszczenia tego przymusu w kontekście wskazanych wyżej umów międzynarodowych, zabraniających pracy przymusowej lub obowiazkowej.

\section{ZGODNOŚĆ REGULACJI POLSKIEJ Z PRAWEM MIËDZYNARODOWYM}

Zgodnie z art. 91 ust. 1 Konstytucji RP, umowa międzynarodowa ratyfikowana za uprzednią zgodą wyrażoną w ustawie ma pierwszeństwo przed ustawą, jeżeli ustawy tej nie da się pogodzić z umową. Istniejący na tej podstawie wymóg stosowania polskiego prawa $\mathrm{w}$ zgodzie z regulacjami międzynarodowymi, które zabraniają stosowania pracy przymusowej lub obowiązkowej poza określonymi, wymienionymi $\mathrm{w}$ nich, sytuacjami, doprowadziła w polskiej literaturze do wyrażenia stanowiska, zgodnie z którym regulacje dotyczące kary ograniczenia wolności, w zakresie, w jakim nakładają na skazanego obowiązek wykonywania pracy na cele społeczne, stanowią przepisy martwe i dlatego nie powinny znaleźć zastosowania $\mathrm{w}$ praktyce ${ }^{30}$.

Powyższe stanowisko oparte jest na literalnej treści konwencji, co - jak się wydaje - nie wyklucza zawężenia pojęcia pracy przymusowej lub obowiązkowej w rozumieniu tych aktów prawnych; jednak nie przez rozszerzającą wykładnię wprowadzonych wyjątków od zakazu, lecz zwężającą funkcjonalną wykładnię samej treści zakazu pracy przymusowej lub obowiązkowej. Zarówno ograniczenie się do postulatu, by właściwe organy dokonały zmiany we wskazanych

\footnotetext{
-Michalską w opracowaniu: W sprawie modelu kary ograniczenia wolności, „Przegląd Prawa Karnego" 1990 , nr 1, s. 31.

${ }^{29}$ Dz. U. Nr 191, poz. 1366 ze zm.

${ }^{30}$ A. Guzik, $O$ dwóch martwych przepisach $w$ Kodeksie karnym, „Jurysta” 1999, nr 2-3, s. 41-42.
} 
konwencjach (i tym samym akceptacja założenia, że do tego czasu będzie dochodzić do ich naruszenia w wewnętrznym polskim porządku prawnym), jak i rezygnacja z pracy na cele społeczne w ramach kary ograniczenia wolności wydaja się bowiem rozwiązaniem niesatysfakcjonującym.

Problem związany $\mathrm{z}$ wykładnią treści umów międzynarodowych $\mathrm{w}$ taki sposób, by regulacja polska przewidująca obowiązek pracy na cele społeczne wykonywanej w ramach kary ograniczenia wolności pozostawała z nimi w zgodzie, dotyczy wszystkich trzech wskazanych wyżej konwencji. Artykuł 2 lit. c Konwencji nr 29 MOP wydaje się wprawdzie w omawianym kontekście stosunkowo bezproblemowy, gdyż wyklucza z zakresu ,,pracy przymusowej lub obowiązkowej" zakazywanej przez tę konwencję wszelka pracę lub usługi wymagane od jakiejś osoby w wyniku skazania jej przez władzę sądową. Jednak wśród warunków takiego wyłączenia wskazano między innymi, że osoba sprawcy nie będzie najęta lub oddana do rozporządzenia jednostkom, prywatnym spółkom lub stowarzyszeniom, co może stanowić problem wtedy, gdy wykonywanie pracy na cele społeczne ma miejsce u tych podmiotów. Możliwość taką dopuszcza art. $56 \S 3$ k.k.w. Wydaje się jednak, że wystarczające do pozostawania w zgodzie z art. 2 lit. c. Konwencji nr 29 MOP będzie utrzymanie wymogu sprawowania pracy „,na cele społeczne”, a nie na własne potrzeby podmiotów, u których skazany odbywa pracę - oraz pozostawianie skazanego w tym czasie pod kontrolą kuratora zawodowego jako gwaranta, że będzie ona faktycznie wykonywana na cele społeczne.

W literaturze zwraca się uwagę, że w raporcie dla Konferencji Państw Rady Europy (a zatem państw sygnatariuszy EKPC) z 1986 r. przyjęto, że: „kara pracy na cele społeczne jest prawdopodobnie najbardziej postępowym alternatywnym środkiem wprowadzanym do europejskiego prawa materialnego w ostatnich 10 latach i jedynym, który wydaje się zawierać wiele możliwości i rodzić wiele nadziei" ${ }^{31}$. Pozwala to przyjąć, że wykonywanie pracy w warunkach kary wolnościowej nie stoi w sprzeczności z zakazem ,„pracy przymusowej lub obowiązkowej" w rozumieniu EKPC. Wprawdzie praca ta nie jest świadczona dobrowolnie i zawarta jest $\mathrm{w}$ niej dolegliwość związana $\mathrm{z}$ wykonywaniem kary kryminalnej, nie ma jednak ona charakteru porównywalnego z pozbawieniem jednostki możliwości rozporządzania swoim czasem i swoja osoba, a jedynie ogranicza ją w tym zakresie w sposób określony ramami ustawy i orzeczeniem sądu. Nie stanowi ona zatem ingerencji w sferę podstawowych praw i wolności człowieka i obywatela ${ }^{32}$.

W odniesieniu do art. 4 ust. 2 EKPC należy zwrócić uwagę na okoliczność, że regulację tę połączono $\mathrm{w}$ jednym artykule $\mathrm{z}$ zakazem trzymania kogokolwiek $\mathrm{w}$ niewoli lub w poddaństwie (art. 4 ust. 1 EKPC), co - jak się wydaje wyznacza kontekst celowościowy tej regulacji. Praca przymusowa lub obowiązkowa będzie zatem praca wykonywana w warunkach zbliżonych do niewoli lub poddaństwa. Konwencja $\mathrm{w}$ sprawie niewolnictwa podpisana w Genewie 25 września 1926 r. określa niewolnictwo jako: „stan czy położenie jednostki, względem której stosowane jest postępowanie w całości lub w części

${ }^{31}$ Cyt. za: M. Szewczyk, op. cit., s. 89.

${ }^{32}$ Por. J. Skupiński, op. cit., s. 61. 
wynikające z prawa własności”. Ponadto w art. 5 tej Konwencji jej strony (w tym Rzeczpospolita Polska) zobowiązały się do przedsięwzięcia kroków potrzebnych do tego, by ,praca przymusowa lub obowiązkowa nie pociagała za soba warunków równoznacznych z niewolnictwem". Wskazana Konwencja dopuszczała przy tym w ograniczonym zakresie pracę przymusową lub obowiązkowa, zastrzegając jednak, że może ona być wymagana (zasadniczo) tylko dla celów publicznych.

Takie ujęcie pracy przymusowej i obowiązkowej może znaleźć oparcie także w Konwencji nr 105 Międzynarodowej Organizacji Pracy o zniesieniu pracy przymusowej (dalej jako: Konwencja nr $105 \mathrm{MOP})^{33}$. Konwencja ta nawiązuje w swej preambule do Konwencji z 1926 r. dotyczącej zniesienia niewolnictwa oraz do Konwencji z 1956 r. w sprawie zniesienia niewolnictwa, handlu niewolnikami oraz instytucji i praktyk zbliżonych do niewolnictwa dążącej do całkowitego zniesienia służebności za długi i poddaństwa. W tej samej preambule wskazano, że ustanowienie Konwencji nr 105 MOP służyć ma zmierzaniu do zniesienia pewnych (a nie wszelkich) form pracy przymusowej lub obowiązkowej - i to takich, które stanowią pogwałcenie praw człowieka określonych w Karcie Narodów Zjednoczonych i proklamowanych w Powszechnej deklaracji praw człowieka. Obowiązek bezwzględnego zniesienia pracy przymusowej lub obowiązkowej został w treści art. 1 Konwencji ograniczony do sytuacji, w której miała ona stanowić: środek nacisku lub wychowania politycznego albo sankcję w stosunku do osób mających lub wypowiadających pewne poglądy polityczne albo manifestujących opozycje ideologiczna wobec ustalonego ustroju politycznego, społecznego lub gospodarczego; metodę mobilizowania albo wykorzystania siły roboczej dla celów rozwoju gospodarczego; środek dyscypliny pracy; karę za udział w strajkach; środek dyskryminacji rasowej, społecznej, narodowej albo religijnej. Są to zatem sytuacje, w których praca przymusowa lub obowiązkowa nie ma służyć społeczności, ale stanowić formę osiągania doraźnych celów politycznych czy gospodarczych. Powyższe rozważania można przenieść na grunt Międzynarodowego paktu praw obywatelskich i politycznych. Również w tym przypadku w art. 8 MPPOP zakaz pracy przymusowej i obowiązkowej (ust. 3) zawarto bowiem w jednym przepisie z zakazem trzymania kogokolwiek w niewoli (ust. 1) lub poddaństwie (ust. 2).

\section{WNIOSKI}

Podsumowanie analizy przyjętych przez ustawodawcę regulacji zwykle ma na celu wskazanie, gdzie zawiera się faktyczny lub potencjalny problem z ich zastosowaniem i jak można go rozwiązać - najczęściej w drodze ingerencji ustawodawczej. Analiza obecnego brzmienia regulacji dotyczacych kary ograniczenia wolności w polskim Kodeksie karnym prowadzi jednak do wniosku, że warstwa słowna nie budzi zastrzeżeń, a ewentualne kwestie problemowe moga pojawić się - i zostać rozwiązane - na etapie wykładni i stosowania prawa.

${ }^{33}$ Dz. U. 1959, Nr 39, poz. 240. 
Trzon kary ograniczenia wolności stanowi wykonywanie nieodpłatnej, kontrolowanej pracy na cele społeczne. Jako że z każdą kara, a w szczególności z karą kryminalną, wiąże się dla sprawcy określona dolegliwość, w wypadku kary ograniczenia wolności dolegliwości tej należy poszukiwać $\mathrm{w}$ związku $\mathrm{z}$ obowiązkiem świadczenia pracy. Sama praca stanowi wprawdzie cenną wartość; jednak konieczność jej świadczenia w ramach kary w sposób określony w ustawie karnej (nieodpłatnie, pod kontrolą organów państwowych, bez możliwości wyboru jej rodzaju i wymiaru) w połączeniu $\mathrm{z}$ ograniczeniami związanymi $\mathrm{w}$ sposób naturalny, $\mathrm{z}$ wykonywaniem kary kryminalnej, można uznać za dolegliwość - i to zarówno wtedy, gdy stanowi ona karę samoistna (jak w prawie rosyjskim), jak i wówczas, gdy jest elementem innej kary (jak kary ograniczenia wolności w prawie polskim).

Okoliczności te muszą być brane pod uwagę już na etapie wymiaru kary. To na tym etapie sąd dobiera bowiem karę i związaną z nią dolegliwość do stopnia winy i uwzględnieniając pozostałe dyrektywy jej wymiaru. Ewentualna modyfikacja kary na etapie jej wykonywania, polegająca w szczególności na zmianie nakładanych na sprawcę dodatkowych obowiązków z art. $72 \S 1$ k.k., powinna być zatem zawsze dokonywana przy zachowaniu poziomu dolegliwości zawartego $\mathrm{w}$ wyroku skazującym. Na stopień dolegliwości nie wypływa natomiast rodzaj faktycznie świadczonej pracy; stąd prawidłowe, jak też uzasadnione od strony praktycznej, jest określanie rodzaju tej pracy dopiero na etapie wykonywania kary. Modyfikacja w tym zakresie może być zatem dokonywana przez organy wykonawcze bez większych ograniczeń - na ile, naturalnie, pozostaje w kontekście art. $53 \S 1$ k.k.w. i uzasadniona jest jego treścia.

Włączenie pracy na cele społeczne do systemu sankcji, jako elementu kary ograniczenia wolności, nie przesądza o jej przymusowym lub obowiązkowym charakterze w rozumieniu umów międzynarodowych wprowadzających zakaz nakładania i egzekwowania takiej pracy. Analiza treści regulacji międzynarodowych wymaga jednak zawsze odniesienia do ich celu, a nie jedynie literalnego brzmienia, które w kontekście sformułowań używanych w porządkach prawnych państw sygnatariuszy konwencji może przyjmować różną treść. Kierowanie się jedynie literalnym brzmieniem regulacji zawartych $\mathrm{w}$ umowach międzynarodowych skutkować może stosowaniem sztucznych rozwiązań, których wprowadzeniu nie towarzyszy dostrzegalna zmiana w zakresie funkcjonowania danej instytucji, lecz służą one jedynie ich dostosowaniu do literalnego brzmienia umowy międzynarodowej. Przykładem takiej sytuacji, w kontekście analizowanej problematyki pracy na cele społeczne, jest wprowadzanie formalnego wymogu ,zgody” skazanego na wykonywanie pracy w warunkach kary ograniczenia wolności, aby uniknąc posądzenia o stosowanie pracy przymusowej lub obowiazkowej. Rozwiązaniem bardziej zasadnym wydaje się $\mathrm{w}$ tym wypadku wykładnia uwzględniająca systemowy kontekst, w jakim umieszczono regulacje zakazujące stosowania pracy przymusowej i obowiązkowej, zrównujące ją z sytuacją niewolnictwa i poddaństwa. Umożliwia ona wyprowadzenie wniosku, że celem zakazu stosowania pracy przymusowej lub obowiązkowej było uniknięcie sytuacji, w których skazany traktowany jest jak przedmiot pozostający w dyspozycji państwa i ,wypożyczany” instytucjom publicznym, a nawet prywatnym dla spełniania ich własnych celów, niepozostających 
w związku z potrzebami społeczności. Uznanie, że praca na cele społeczne w ujęciu prezentowanym obecnie przez Kodeks karny nie spełnia tych negatywnych kryteriów, uprawnia do przyjęcia, że nie jest to praca przymusowa ani obowiązkowa w kontekście, w jakim zabraniają ich umowy międzynarodowe sygnowane przez Rzeczpospolitą.

Jeżeli zatem praca społecznie użyteczna została nałożona przez sąd zgodnie z dyrektywami wymiaru kary, a zatem w szczególności w wymiarze współmiernym do stopnia winy oraz przy uwzględnieniu dolegliwości związanej z innymi obowiązkami nałożonymi na sprawcę (z grupy obowiązków fakultatywnych przewidzianych w art. 72 k.k.), a następnie jest ona wykonywana przy poszanowaniu praw skazanego jako osoby i jako pracownika, to brak jest podstaw do przypisywania jej charakteru niedopuszczalnej dolegliwości - zarówno na gruncie prawa polskiego, jak i regulacji międzynarodowych.

\section{dr Elżbieta Hryniewicz}

Uniwersytet im. Adama Mickiewicza w Poznaniu

hryniew@amu.edu.pl

\section{COMPULSORY COMMUNITY WORK AS AN ELEMENT OF CRIMINAL SANCTION}

\section{Summary}

The object of the analysis is a duty of unpaid controlled work for the community as an element of punishment of restricted freedom in Polish criminal law. The paper presents the function of compulsory work in Polish criminal codes of 1932, 1969 and 1997. It also shows, on the example of the Criminal Code of the Russian Federation, that it is possible to differentiate between a punishment of restricted liberty and a punishment of compulsory work. Next, the authoress attempts to answer the question whether the duty of work for the community can be seen as an inconvenience characteristic of criminal punishment. Finally, the compulsory character of work is being examined to establish whether that kind of penalty is in conformity with the provisions of international treaties that prohibit forced and obligatory labour, to which the Republic of Poland is a signatory. 
Copyright of Journal of Law, Economics and Sociology is the property of Faculty of Law and Administration of Adam Mickiewicz University in Poznan and its content may not be copied or emailed to multiple sites or posted to a listserv without the copyright holder's express written permission. However, users may print, download, or email articles for individual use.

Właścicielem praw autorskich do „Ruchu Prawniczego, Ekonomicznego i Socjologicznego” jest Wydział Prawa i Administracji Uniwersytetu im. Adama Mickiewicza w Poznaniu. Zawartość czasopisma nie może być kopiowana, przesyłana do innych stron internetowych bądź zamieszczana na blogach bez pisemnej zgody wydawcy. Niemniej artykuły można drukować, kopiować lub przesyłać w formie elektronicznej na własny użytek. 